\title{
Smoking Cessation Year
}

National Cancer Institute

\section{Source}

National Cancer Institute. Smoking Cessation Year. NCI Thesaurus. Code C156425.

The year in which an individual quit smoking. 